\title{
NEKOMPAKTINIO MIOKARDO KARDIOMIOPATIJA. KLINIKINIS ATVEJIS
}

\author{
Gabrielè Guščiūtè \\ Vilniaus universiteto Medicinos fakultetas
}

\begin{abstract}
Raktažodžiai: nekompaktinio miokardo kardiomiopatija, nekompaktiškumas, širdies nepakankamumas, echokardiografija, širdies magnetinio rezonanso tomografija.
\end{abstract}

\begin{abstract}
Santrauka
Nekompaktinio miokardo kardiomiopatija (NMK) yra reta liga, kuriai būdingas izoliuotas skilvelių nekompaktiškumas, pasireiškiantis ryškia miokardo trabekuliarizacija, plonu kompaktinio miokardo sluoksniu ir giliomis tarptrabekulinemis ertmėmis. Šiame darbe apibendrinama informacija apie NMK patogenezę, klinikinị pasireiškimą, diagnostikos ir gydymo naujienas.

Pristatomas NMK sergantis pacientas, kuriam diagnozè nustatyta 57 metų amžiaus. Pateikiama jo ligos istorija bei būklè, praèjus penkeriems metams nuo diagnozès nustatymo.

Nesant aiškių diagnostikos kriterijų, tikslus ligos paplitimas iki šiol nèra žinomas. Tai genetiškai heterogeninè liga, dažniausiai diagnozuojama ankstyvoje vaikystẻje. Identifikuoti tam tikri genai, atsakingi už NMK, tačiau genų mutacijos nèra specifinès. Klinikinis pasireiškimas varijuoja nuo simptomų nebuvimo iki širdies nepakankamumo, tromboembolinių komplikacijų ir aritmijų. Pagrindinis tyrimo metodas yra echokardiografija, tačiau pastaruoju metu vis dažniau atliekama širdies magnetinio rezonanso tomografija. Pristatomi nauji diagnostikos metodai, kurie ateityje palengvintu diagnostiką klinikineje praktikoje. Specifinio ligos gydymo nèra, jis nukreiptas i pagrindines NMK klinikines išraiškas: širdies nepakankamumą, aritmijas ir sisteminius embolinius ịvykius. Svarbiausias iššūkis, susijęs su nekompaktinio miokardo kardiomiopatija, yra aiškiai diferencijuoti ši sutrikimą nuo anatominių ir struktūrinių variantų, būdingų sveikoms širdims, ir kitų kardiomiopatijų, nes prognozè ir gydymo taktika skiriasi. Diagnozuojant reikia remtis multimodalinio ištyrimo duomenimis.
\end{abstract}

\section{Ivadas}

Nekompaktinio miokardo kardiomiopatija yra reta liga, kuriai būdingas izoliuotas skilvelių nekompaktiškumas skilvelių sienelès anatomijos ypatumas, pasireiškiantis ryškia miokardo trabekuliarizacija, plonu kompaktinio miokardo sluoksniu ir giliomis tarptrabekulinėmis ertmėmis, susisiekiančiomis su kairiojo skilvelio ertme [1]. Dažniausiai nekompaktiškumas randamas kairiojo skilvelio miokarde, rečiau - dešiniajame skilvelyje arba abiejuose skilveliuose kartu [2]. Amerikos širdies asociacija klasifikuoja NMK kaip genetinę kardiomiopatiją (KMP) [3], o Europos kardiologų draugijos ji apibrěžiama kaip neklasifikuojama KMP [4]. Ilgą laiką patologinio nekompaktiškumo atsiradimas buvo aiškinamas miokardo vystymosi sutrikimu intrauteriniu laikotarpiu, tačiau dabar ši hipotezè kvestionuojama, nes diagnozuojama ịgytų ir potencialiai grịžtamų atvejų [5]. Apie NMK pradèta kalbèti prieš tris dešimtmečius. Per ši laikotarpi tobulëjo diagnostikos ir gydymo priemonès, tačiau iki šiol nèra visuotinai priimtų diagnostikos kriterijų ir specifinio gydymo. Svarbu, kad sveikatos priežiūros specialistai atpažintų ir diferencijuotų šią ligą nuo kitų būklių ir kardiomiopatijų, nes gydymas ir prognozė gali ženkliai skirtis.

Tyrimo tikslas - apžvelgti, ką iki šiandien žinome apie šią daug klausimų keliančią kardiomiopatiją, apibendrinti diagnostikos kriterijus, pristatyti naujus diagnostikos metodus ir gydymo galimybes.

\section{Klinikinis atvejis}

57 metų vyras skundèsi dusuliu nedidelio fizinio krūvio metu, kuris tęsèsi apie 3 mėnesius. Iki pirmujų simptomų pacientas jautèsi sveikas. Dusulys atsirado kartu su febriliu karščiavimu ir kosuliu. Pacientas i gydytojus nesikreipè, 5 dienas gydèsi antipiretikais. Karščiavimas praejo, tačiau išliko dusulys, didelis nuovargis, naktinis produktyvus kosulys, atkosėdavo skaidrių skreplių. Per 3 mėnesius neteko $14 \mathrm{~kg}$ kūno masès. Praejjus 3 mėnesiams nuo simptomų pradžios, buvo hospitalizuotas, nustatytas ir gydytas plaučių užde- 
gimas, pirmą kartą diagnozuotas širdies nepakankamumas (C stadija, NYHA III-IV f. kl.). Po gydymo išliko naktinis kosulys, dusulys nedidelio fizinio krūvio metu. Ambulatoriškai atlikta širdies echoskopija: kairiojo skilvelio išstūmimo frakcija (IF) 25 proc., išsiplètusios dešiniosios širdies ertmès, plautinès hipertenzijos požymiai. Dẻl išliekančių simptomų ir pakitimų širdies echoskopijoje, atsiųstas ị prièmimo skyrių, kuriame buvo konsultuotas kardiologo ir hospitalizuotas i kardiologijos skyrių tolesniam ištyrimui ir gydymui.

Prièmimo skyriuje tiriant objektyviai širdies veikla ritmiška, tachikardiška, širdies susitraukimo dažnis (ŠSD) $102 \mathrm{k} / \mathrm{min}$, arterinis kraujospūdis (AKS) 110/60 mmHg. Plaučiuose alsavimas vezikulinis abipus, be karkalų. Palpuojant pilvas minkštas, kepenų kraštas čiuopiamas apie $7 \mathrm{~cm}$ žemiau dešiniojo šonkaulių lanko. Periferinių edemų nèra.

Bendras kraujo tyrimas be pakitimų. Biocheminiame kraujo tyrime: ženkliai padidëjęs BNP $(2663,2 \mathrm{ng} / \mathrm{l})$, padidejjusi bendro cholesterolio $(6,22 \mathrm{mmol} / \mathrm{l})$ bei MTL- cholesterolio koncentracija $(4,11 \mathrm{mmol} / \mathrm{l})$. Kiti rodikliai be žymių patologinių pakitimų. Elektrokardiogramoje (EKG) stebimi nespecifiniai pakitimai: ritmas sinusinis, $82 \mathrm{k} / \mathrm{min}$, kairiojo prieširdžio (KP) hipertrofija ir repoliarizacijos sutrikimas.

Atlikta transtorakalinė echokardiografija, išvada: nekompaktinio miokardo KMP vaizdas, ženklus kairiojo skilvelio (KS) viršūnès, užpakalinès ir šoninès sienelių bei dešiniojo skilvelio (DS) apatinès sienelès miokardo nekompaktiškumas. KS ir DS ertmių dilatacija. KS silpnumas, ženkliai padidèjęs KS prisipildymo slègis. Ženkliai sumažejusi DS inotropija. II ${ }^{0} \mathrm{KP}$ ir $\mathrm{I}^{0}$ dešiniojo prieširdžio (DP) dilatacija. Reliatyvus I ${ }^{0}$ mitralinio vožtuvo nesandarumas.

Didžiausias nekompaktiškojo ir kompaktiškojo sluoksnių santykis 1,4/0,6 cm (>2). Nekompaktiškasis sluoksnis formuoja pseudoendokardą. Bendroji inotropija ženkliai sumažejusi - KS išstūmimo frakcija (IF) 10-15 proc., segmentinè kontrakcija nesutrikusi. Remiantis aprašytais pakitimais, buvo įtarta nekompaktinio miokardo kardiomiopatija.

Diagnozės patikslinimui atlikta širdies magnetinio rezonanso tomografija (ŠMRT). Išvada: visų širdies ertmių dilatacija. KS bendras silpnumas, IF - 24 proc., izoliuoto šoninès sienelès nekompaktiškumo (hipertrabekuliarizacijos) vaizdas. DS IF sumažejusi iki 37 procentų. Vizualiai $\mathrm{I}^{0}$ mitralinio ir triburio vožtuvų nesandarumas. Fibroziniai pakitimai KS ir DS jungtyse. ŠMRT vaizdas neprieštarauja dilatacinei KMP. Skysčio pėdsakai dešiniosios pleuros ertmèje.

Matoma KS lateralinès sienelès (midventrikuliariai - viršūnejje) pagausẻjusi trabekuliarizacija ir sienelès suplonejjimas iki 3-4 mm, trabekulių ir sienelès santykis 3:1. Patvirtinamas echokardiografijoje matyto izoliuoto nekompaktiškumo (hipertrabekuliarizacijos) vaizdas.

Remiantis klinikinių, laboratorinių ir instrumentinių ty- rimų duomenimis, nustatyta diagnozè - nekompaktinio miokardo kardiomiopatija. Širdies nepakankamumas, C stadija, NYHA III funkcinè klasè. Dislipidemija.

Pacientas gydytas konservatyviai: karvediloliu $(3,125$ $\mathrm{mg} \times 2 \mathrm{k} / \mathrm{d})$, spironolaktonu $(25 \mathrm{mg} \times 1 \mathrm{k} / \mathrm{d})$, digoksinu $(0,25$ $\mathrm{mg} \times 1 \mathrm{k} / \mathrm{d}$, kas antrą dieną), atorvastatinu (30 mg x 1k/d). Gydymo eigoje sumažejo dusulys ir bendras silpnumas. Pagerèjus būklei, pacientas išleistas ị namus, tęstas paskirtas medikamentinis gydymas.

Vèlesnių vizitų pas kardiologą metu pacientas skundèsi išlikusia bloga krūvio tolerancija, varginančiu silpnumu. Abulatoriškai užrašius EKG - sinusinis ritmas 74 k/min, išlikę KP hipertrofijos požymiai. Matomos naujai atsiradusios skilvelinès ekstrasistolès ir kairiosios Hiso pluošto kojytès blokada (KHPKB). Pacientas toliau stebimas ir tęsiamas tas pats gydymas, papildomai pridetas diuretikas torazemidas (10 mg x 1k/d kas 2 dienas).

Praejus penkeriems metams nuo diagnozès nustatymo, pacientas vèl atvyko ị prièmimo skyrių, nes nedidelio fizinio ir emocinio krūvio metu pajuto silpnumą, išpylè prakaitas, jaute širdies plakimus ir trumpam prarado sąmonę, o pabudęs pajuto aštrų skausmą krūtinèje. Pacientas buvo sąmoningas, kontaktiškas. AKS 95/62 mmHg, širdies veikla ritmiška, ŠSD $90 \mathrm{k} / \mathrm{min}$. Plaučiuose alsavimas vezikulinis, susilpnejjęs visame plote, abipus girdima stazinių karkalų. Pilvas minkštas, neskausmingas. Blauzdų edemos. Priemimo skyriuje užrašytoje EKG ritmas sinusinis, ŠSD 90 k/min, KHPKB.

Negalint atmesti ūminio miokardo infarko, skubiai atlikta koronarografija. Išvada: vainikinès arterijos be ženklių stenozių, stebima koronarinè fistulè iš septalinès šakos ị skilveli. Bendrame kraujo tyrime pakitimų nèra. Biocheminiame kraujo tyrime: padideję̨ BNP $(1085,9$ ng/l), išlieka padidèjusi bendrojo cholesterolio $(5,81 \mathrm{mmol} / \mathrm{l})$ ir MTL-cholesterolio $(3,34 \mathrm{mmol} / \mathrm{l}))$ koncentracija. Troponinas I nepadidejęs. Insktų funkcijos rodikliai be patologinių pakitimų.

Po atliktos koronarografijos gydytas kardiologinès reanimacijos skyriuje, taikyta infuzinè skysčiu terapija, intraveniniai diuretikai, elektrolitų disbalanso korekcija. Esant stabiliai būklei, tolesniam gydymui perkeltas į kardiologijos skyrių.

Skyriuje atlikta echokardiografija, išvada: dilatacinès KMP vaizdas, KS dilatacija ir silpnumas, asinchroniška KS kontrakcija, KS IF apie 20 procentų. KS diastolinė disfunkcija, padidèjęs KS pildymosi slègis. DS ertmé neišsiplètusi, sutrikusi DS funkcija, sumažejusi inotropija . I ${ }^{0} \mathrm{KP}$ dilatacija. Gausi KS užpakalinès sienelès vidurinių-viršūninių segmentų trabekuliarizacija.

Apibendrinant, praejus 5 metams nuo NMK diagnozès nustatymo, išliko bloga fizinio krūvio tolerancija. Tiriant objektyviai, atsirado periferinès edemos ir stazinių karkalų plaučiuose, tačiau stacionarinio gydymo fone šie požymiai 
išnyko. Inkstų funkcija gera. Išliko didelė BNP koncentracija kraujyje, tačiau 5 metų dinamikoje mažèjimas (2663,2 ng/ là1085,9). KS IF stabiliai maža, apie 20 procentų. Gydymo pabaigoje paciento būkle patenkinama, hemodinamika stabili. Pacientas išrašytas tolesniam ambulatoriniam gydymui, rekomenduojami vaistai: torazemidas $(20 \mathrm{mg} \mathrm{x} 1 \mathrm{k} / \mathrm{d})$, spironolaktonas $(25 \mathrm{mg} \mathrm{x} 1 \mathrm{k} / \mathrm{d})$, digoksinas $(0,25 \mathrm{mg}$ kas antrą dieną), ivabradinas (5 mg x $2 \mathrm{k} / \mathrm{d})$, karvedilolis (12,5 $\operatorname{mg} \times 2 \mathrm{k} / \mathrm{d}$ ).

\section{Aptarimas}

NMK apibūdinama kaip neklasifikuojama kardiomiopatija, kuriai būdinga ryški skilvelių trabekuliarizacija ir gilios tarptrabekulinès ertmès, susisiekiančiomis su skilvelių ertme, nesant kitų širdies anomalijų [4]. Per pastaruosius 34 metus neinvaziniai diagnostikos metodai tobulèjo ir buvo diagnozuota nemažai naujų NMK atvejų, tačiau tikrasis paplitimas iki šiol nèra žinomas. Tyrimas, atliktas su vaikais, sergančiais pirmine kardiomiopatija, parodè, kad 9 proc. pacientų sirgo NMK [6].

Klinikinis ligos pasireiškimas ir diagnozavimo amžius smarkiai varijuoja. Dažnai pacientai būna asimptominiai arba pasireiškia šios pagrindinès komplikacijos: KS sistolinè ar diastolinè disfunkcija, širdies nepakankamumo požymiai, aritmijos, tromboemboliniai įvykiai [7]. Sistolinè KS disfunkcija greičiausiai atsiranda dèl sąlyginès išemijos, kurią sukelia neatitikimas tarp miokardo deguonies poreikio ir aprūpinimo deguonimi. Diastolinè KS disfunkcija susijusi su sutrikusia relaksacija ir restrikcija dèl gausių miokardo trabekulių ir fibrozės [8]. Dažniausiai pasireiškiančios aritmijos yra prieširdžių virpèjimas ir skilvelinès tachiaritmijos [7]. Tromboemboliniai įvykiai: insultas, praeinantys smegenų išemijos priepuoliai susiję su trombų formavimusi tarp trabekulių gausiai trabekuliarizuotame skilvelyje dèl sumažèjusios KS sistolinès funkcijos ir KP ertmèje dèl prieširdžių virpèjimo [7]. Pradiniuose tyrimuose vidutinis diagnozès nustatymo amžius buvo 7 metai [9], bet NMK vis dažniau diagnozuojama ir suaugusiems pacientams. Viename tyrime su aštuoniais pacientais vidutinis diagnozès nustatymo amžius buvo 58 metai (nuo 28 iki 80 metų) [10]. Dauguma tyrimų rodo, kad vyrai serga dažniau nei moterys $[9,10]$. Šiuo atveju mūsų paciento pirminis ligos pasireiškimas buvo širdies nepakankamumo požymiai: sistolinė KS disfunkcija, dusulys menko fizinio krūvio metu, bendras silpnumas, nuovargis. Pirmieji simptomai pasireiškè gana vèlai, nekompaktinio miokardo kardiomiopatijos diagnozè nustatyta sulaukus 57 metų.

NMK yra genetiškai heterogeninis susirgimas, yra aprašytų sporadinių ir šeiminių miokardo nekompaktiškumo formų. Pradiniuose tyrimuose, kuriuose daugiausia buvo tiriami vaikai, pusės pacientų šeimos narių taip pat buvo diagnozuotas miokardo nekompaktiškumas [9]. Tiriant suaugusius pacientus, 18 proc. atvejų buvo teigiama šeiminè anamnezė [11]. Yra nustatyti tam tikri genai, kurie gali būti atsakingi už nekompaktiškumo vystymąsi, suaugusiụų NMK formos dažniausiai paveldimos autosominiu dominantiniu būdu [12]. Šiuo atveju paciento šeiminè anamnezè nèra žinoma. Rekomenduojama paciento pirmos eilès šeimos narių patikra, atliekant echokardiografiją dèl ankstyvojo ligos nustatymo, būklès stebejimo ir galimų komplikacijų profilaktikos [13]. NMK diferencijuojama nuo kitų kardiomiopatijų, tačiau būna atvejų, kai miokardo nekompaktiškumas egzistuoja kartu su dilatacine kardiomiopatija [14], kaip ir mūsų aprašytajam pacientui.

Standartinis NMK diagnostikos metodas yra echokardiografija. Nors iki šiol nèra bendrujų susirgimo diagnostikos kriterijų, siūlomi ịvairių autorių variantai, tačiau dažniausiai naudojami kriterijai yra R. Jenni ir kolegų [1], kurie teigia, kad santykis tarp nekompaktinio ir kompaktinio miokardo sluoksnių turi būti $>2$, matuojant dvimačiu režimu sistolès pabaigoje, parasterniniame trumposios ašies vaizde. Matomas sustorèjęs miokardo sluoksnis su ryškiomis ir gausiomis trabekulèmis bei tarptrabekulinėmis ertmėmis (1 pav.), nèra kitų širdies anomalijų [1]. Kartu galimi nespecifiniai požymiai: KS diastolinè disfunkcija, sumažejusi globali KS sistolinė funkcija, trombai kairiajame skilvelyje. Mūsų pacientą ištyrus echokardiografiškai, buvo matomi nekompaktinio ir kompaktinio miokardo sluoksniai, kurių tarpusavio santykis yra 2,3 ir atitinka pasiūlytus patologinio nekompaktiškumo kriterijus.

Pastaruoju metu echokardiografiniai tyrimai tobulèja ir atsiranda naujų metodų, kurie teikia galimybę ịvertinti miokardo funkciją ir diferencijuoti normalų trabekuliarizuotą

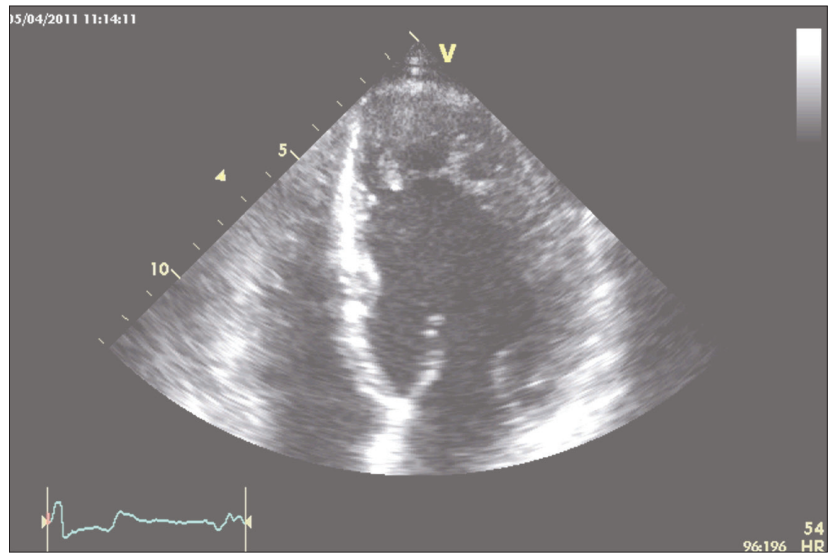

1 pav. Transtorakalinė širdies echoskopija: tipinis dviejų sluoksnių miokardas su ryškiomis trabekulèmis ir giliomis tarptrabekulinèmis ertmèmis 
miokardą nuo NMK [15]. Naujieji metodai yra doplerinė audinių echokardiografija, miokardo deformacijos (angl. strain) ir deformacijos greičio (angl. strain rate) matavimai, atliekami taškelių žymejjimo metodika (angl. speckle tracking) [15]. Kairiojo skilvelio užsisukimas (angl. left ventricular twist) buvo nustatytas taškelių žymejjimo metodika [16]. Visoje kontrolineje grupeje ir pacientams su dilatacine KMP, rotacija buvo pagal laikrodžio rodyklę KS bazèje ir prieš laikrodžio rodyklę viršūnèje (2 pav.). Pacientų su nekompaktiniu miokardu rotacija yra smarkiai sumažejusi ir daugumos užsisukimas buvo vienoda kryptimi KS bazèje ir viršūnèje. Vadinasi, KS rotacija (užsisukimas) gali būti naujas objektyvus ir praktiškas nekompaktiškumo diagnostinis kriterijus [16]. Realaus laiko trimate echokardiografija (RL3DE) yra naujas metodas, kuriuo taip pat vertinama KS užsisukimo mechanika. Jis gali būti kombinuojamas kartu su taškelių žymejjimo metodika [17]. RL3DE naudingas vertinant KS funkciją ir trabekulių kiekị, kuris yra nepakankamai ivvertinamas atliekant $2 \mathrm{D}$ vaizdinimą. Kol kas šie metodai reikalauja detalesnių studijų ir dar nèra plačiai taikomi klinikinejje praktikoje.

Širdies magnetinio rezonanso tomografija atliekama diagnozės patikslinimui, tai ypač naudingas tyrimas geram širdies viršūnès ir dešiniojo skilvelio vizualizavimui, matomas geros rezoliucijos vaizdas visose plokštumose. Matuojamas nekompaktinio ir kompaktinio miokardo sluoksnių santykis, kuris turi būti >2,3 [18]. Mūsų nagrinèjamam pacientui išmatuotas santykis yra 3, tad patvirtinamas echokardiografiškai nustatytas patologinis miokardo nekompaktiškumas.

Pataruoju metu pradètas taikyti naujas, vadinamasis fraktalų analizès metodas (angl. fractal analysis), kuriuo atliekamas kiekybinis trabekuliarizacijos vertinimas. Fraktalų analize - tai metodas, skirtas ịvertinti sudètingas geometrines

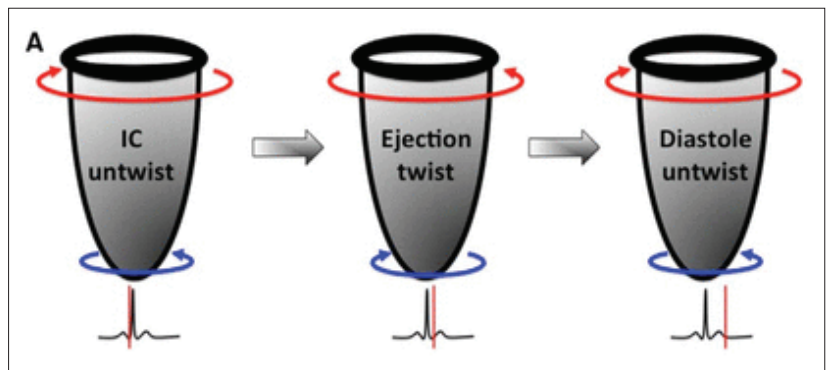

2 pav. Kairiojo skilvelio užsisukimas (angl. left ventricular twist) Raudona rodyklè (viršuje) - KS bazès rotacija. Mėlyna rodyklè (apačioje) - KS viršūnès rotacija

Šaltinis: Alaa Mabrouk Salem Omar et al. Copyright (C) 2015, American Heart Association, Inc. formas biologinèse struktūrose ir šiuo metu plačiai taikomas analizuojant plaučių, smegenų, kraujagyslių vaizdus. Matuojamas vienetų neturintis rodiklis - fraktalinè dimensija, kuri parodo, kaip objektas užpildo erdvę. Šiuo metodu matuojama endokardo ir miokardo ribos fraktalinè dimensija, kurios skaitinè reikšmè tuo didesnè, kuo sudètingesnè yra figūra. G. Captur ir bendraautorių tyrime [19] matuota endokardo ir miokardo ribos fraktalinè dimensija buvo reikšmingai didesnè pacientų su NMK, nei sveikų savanorių. Tokia trabekuliarizacijos analizè leidžia nustatyti NMK diagnozę didesniu tikslumu, nei dabartiniai ŠMRT metodai ir tai yra daug žadanti nauja metodika [19].

ŠMRT galima vertinti vèlyvaji gadolinio kaupimą, kuris rodo miokardo fibrozę. G. Nucifora ir bendrautorių tyrimas [20] parodè, kad vélyvas gadolinio kaupimas stebimas daugiau nei pusei pacientų su izoliuotu skilvelių miokardo nekompaktiškumu, o jo radimas ir išplitimas susijęs su sunkesniu ligos klinikiniu pasireiškimu ir KS sistoline disfunkcija (mažesne IF).

Specifinio NMK gydymo nèra, jis varijuoja priklausomai nuo klinikinio pasireiškimo. Gydymas nukreiptas ne ị patị nekompaktiškumą, o ị jo komplikacijas: tinkamą širdies nepakankamumo, aritmijų gydymą, oralinę antikoaguliaciją esant padidejusiai tromboembolinių ịvykių rizikai dèl prieširdžiu virpėjimo ar sumažèjusios KS IF (<40\%). Dèl paciento gydymo sprendžiama individualiai, priklausomai nuo jo būklès, jei yra indikacijų, reikia apsvarstyti kardioverterio defibriliatoriaus implantavimą ar įtraukimą ị širdies transplantacijos sąrašą. Šiuo atveju pacientui pasireiškè sistolinis širdies nepakankamumas su sumažèjusia KS IF, todèl skirtas gydymas pagal dabartines širdies nepakankamumo gaires [21]. Jei neveiksmingas standartinis medikamentinis širdies nepakankamumo gydymas, širdies transplantacija yra galutinè gydymo baigtis. Yra žinoma sėkmingų transplantacijos atvejų, vienas iš jų aprašytas Lietuvoje [22]. Širdies transplantacija sékmingai atlikta VUL Santaros klinikose pacientui su izoliuota nekompaktinio miokardo kardiomiopatija, galutinès stadijos širdies nepakankamumu ir pasikartojančiais tromboemboliniais ịvykiais.

NMK susijusi su dideliu vaikų ir suaugusiųų mirtingumu ir mirštamumu. Baigtis labiau susijusi su ligos sunkumu ir klinikiniu pasireiškimu diagnozès nustatymo metu, nei su diagnoze per se. Sisteminė tyrimų su ilgalaikiu (39 mẻnesių) pacientų stebejjimu apžvalga parodè, kad bendras mirštamumas buvo 14 proc. per visą stebejjimo laikotarpị, pusè iš jų buvo dèl staigaus širdies sustojimo. 5 proc. pacientų mirè dèl širdies nepakankamumo [23]. Didelis tromboembolinių įvykių (24\%) ir skilvelinių tachikardijų (41 \%) dažnis lemia prastą klinikinę prognozę pacientams su sutrikusia sistoline KS funkcija [23]. 


\section{Išvados}

1. Svarbiausias iššūkis, susijęs su nekompaktinio miokardo kardiomiopatija, yra aiškiai diferencijuoti šį sutrikimą nuo sveikoms širdims būdingų anatominių ir struktūrinių variantų, bei kitų kardiomiopatijų. 2. Kol nèra aiškių diagnostikos kriterijų, reikètų remtis multimodalinio tyrimo rezultatais: atsižvelgti į bendrą klinikinį vaizdą, echokardiografinius kriterijus matuojant nekompaktinio ir kompaktinio miokardo sluoksniu santyki, pakitimus elektrokardiogramoje, širdies magnetinio rezonanso duomenis. 3. Vilties teikia nauji neinvazinių tyrimų metodai, kuriuos taikant palengvètų tikslios diagnozès nustatymas, tai yra: doplerinè audinių echokardiografija, miokardo deformacijos ir deformacijos greičio matavimai, atlikti taškelių žymėjimo metodika, realaus laiko trimate echokardiografija bei širdies magnetinio rezonanso tomografijos fraktalų analizès metodas. Kol kas šie tyrimai nèra plačiai taikomi klinikinejje praktikoje, tačiau yra daug žadantys metodai.

4. Gydymas nukreiptas ị komplikacijas: širdies nepakankamumą, aritmijas. Esant indikacijų, skirti antikoaguliantus tromboembolijų profilaktikai, implantuoti kardioverteri defibriliatorių tam, kad būtų išvengta staigios mirties dèl skilvelinių ritmo sutrikimų. Dẻl gana didelio mirštamumo ir prastos prognozès, pacientų pirmos eilès giminèms rekomenduojama patikra atliekant echokardiografiją, kad būtų taikoma ankstyvoji komplikacijų profilaktika.

\section{Literatūra}

1. Jenni R, Oechslin E, Schneider J, Attenhofer Jost C, Kaufmann PA. Echocardiographic and pathoanatomical characteristics of isolated left ventricular non-compaction: a step towards classification as a distinct cardiomyopathy. Heart 2001;86:666-71. https://doi.org/10.1136/heart.86.6.666

2. Ranganathan A, Ganesan G, Sangareddi V, et al. Isolated noncompaction of right ventricle-a case report. Echocardiography 2012;29:E169-72.

https://doi.org/10.1111/j.1540-8175.2012.01671.x

3. Maron BJ, Towbin JA, Thiene G, et al. Contemporary definitions and classification of the cardiomyopathies: an American Heart Association Scientific Statement from the Council on Clinical Cardiology, Heart Failure and Transplantation Committee; Quality of Care and Outcomes Research and Functional Genomics and Translational Biology Interdisciplinary Working Groups; and Council on Epidemiology and Prevention. Circulation 2006;113:1807-16.

https://doi.org/10.1161/CIRCULATIONAHA.106.174287

4. Elliott P, Andersson B, Arbustini E, et al. Classification of the cardiomyopathies: a position statement from the European Society Of Cardiology Working Group on Myocardial and Pericardial Diseases. Eur Heart J 2008;29:270-276.

https://doi.org/10.1093/eurheartj/ehm342
5. Gati S, Papadakis M, Papamichael ND, et al. Reversible de novo left ventricular trabeculations in pregnant women: implications for the diagnosis of left ventricular noncompaction in low-risk populations. Circulation 2014;130:475-83.

https://doi.org/10.1161/CIRCULATIONAHA.114.008554

6. Andrews RE, Fenton MJ, Ridout Da, et al. British Congenital Cardiac Association. New-onset heart failure due to heart muscle disease in childhood: A prospective study in the United kingdom and Ireland. Circulation 2008;117:79-84.

https://doi.org/10.1161/CIRCULATIONAHA.106.671735

7. Ritter M, Oechslin E, Sutsch G, et al. Isolated noncompaction of the myocardium in adults. Mayo Clin Proc 1997;72:26-31. https://doi.org/10.4065/72.1.26

8. Agmon Y, Connolly HM, Olson LJ, et al. Noncompaction of the ventricular myocardium. J Am Soc Echocardiogr 1999;12:859-63. https://doi.org/10.1016/S0894-7317(99)70192-6

9. Chin TK, Perloff JK, Williams RG, et al. Isolated noncompaction of left ventricular myocardium. A study of eight cases. Circulation 1990;82:507-13.

https://doi.org/10.1161/01.CIR.82.2.507

10. Pignatelli RH, McMahon CJ, Dreyer WJ, Denfield SW, Price J, Belmont JW, et al. Clinical characterization of left ventricular noncompaction in children: a relatively common form of cardiomyopathy. Circulation 2003;108:2672-8. https://doi.org/10.1161/01.CIR.0000100664.10777.B8

11. Oechslin EN, Attenhofer Jost CH, Rojas JR, et al. Long-term follow-up of 34 adults with isolated left ventricular noncompaction: A distinct cardiomyopathy with poor prognosis. J Am Coll Cardiol 2000;36:493-500. https://doi.org/10.1016/S0735-1097(00)00755-5

12. Ackerman MJ, Priori SG, Willems S, Berul C, Brugada R, Calkins H, et al. HRS/EHRA expert consensus statement on the state of genetic testing for the channelopathies and cardiomyopathies: this document was developed as a partnership between the Heart Rhythm Society (HRS) and the European Heart Rhythm Association (EHRA). Europace 2011;13:1077-109 https://doi.org/10.1093/europace/eur245

13. Caliskan K, Michels M, Geleijnse ML, et al. Frequency of asymptomatic disease among family members with noncompaction cardiomyopathy. Am J Cardiol 2012;110:1512-7. https://doi.org/10.1016/j.amjcard.2012.07.009

14. Carrilho-Ferreira P, Almeida AG, Pinto FJ. Non compaction Cardiomyopathy: prevalence, prognosis, pathoetiology, genetics, and risk of cardioembolism. Curr Heart Fail Rep 2014;11:393.

https://doi.org/10.1007/s11897-014-0227-3

15. Kohli SK, PantazisAA, Shah JS, Adeyemi B, JacksonG, McKenna WJ, et al. Diagnosis of left-ventricular non-compaction in patients with left-ventricular systolic dysfunction: time for a reappraisal of diagnostic criteria? Eur Heart J 2008;29:89-95. https://doi.org/10.1093/eurheartj/ehm481 
16. Dalen BM, Caliskan K, Soliman OI, Nemes A, Vletter WB, Ten Cate FJ, Geleijnse ML. Left ventricular solid body rotation in non-compaction cardiomyopathy: a potential new objective and quantitative functional diagnostic criterion? Eur J Heart Fail 2008;10:1088-1093. https://doi.org/10.1016/j.ejheart.2008.08.006

17. Koo B, Choi D, Ha JW, Kang S, Chung N, Cho SY. Isolated noncompaction of the ventricular myocardium: contrast echocardiographic findings and review of the literature. Echocardiography 2002;19:153-6. https://doi.org/10.1046/j.1540-8175.2002.00153.x

18. Petersen SE, Selvanayagam JB, Wiesmann F, Robson MD, Francis JM, Anderson RH, et al. Left ventricular non-compaction: Insights from cardiovascular magnetic resonance imaging. J Am Coll Cardiol 2005;46:101-5. https://doi.org/10.1016/j.jacc.2005.03.045

19. Captur G, Muthurangu V, Cook C, Flett AS, Wilson R, Barison A, et al. Quantification of left ventricular trabeculae using fractal analysis. J Cardiovasc Magn Reson. 2013;15:36. https://doi.org/10.1186/1532-429X-15-36

20. Nucifora G, Aquaro GD, Pingitore A, Masci PG, Lombardi M. Myocardial fibrosis in isolated left ventricular non-compaction and its relation to disease severity. Eur J Heart Fail. 2011;13:170-6. https://doi.org/10.1093/eurjhf/hfq222

21. Ponikowski P, Voors AA, Anker SD, Bueno H, Cleland JGF, Coats AJS, Falk V, González-Juanatey JR, et al. ESC guidelines for the diagnosis and treatment of and chronic heart failure 2016. Eur Heart J 2016: 37: 2129-200

https://doi.org/10.1093/eurheartj/ehw128

22. Glaveckaite S, Ručinskas K, Čelutkienė J, et al. Heart transplantation in an adult patient with isolated noncompaction of the left ventricular myocardium. Medicina (Kaunas) 2010;46(3):193-9. https://doi.org/10.3390/medicina46030027

23. Bhatia NL, Tajik AJ, Wilansky S, Steidley DE, Mookadam F. Isolated noncompaction of the left ventricular myocardium in adults: a systematic overview. J Card Fail 2011; 17:9,:771-778. https://doi.org/10.1016/j.cardfail.2011.05.002

\section{NONCOMPACTION CARDIOMYOPATHY. CASE REPORT \\ G. Guščiūtè}

Keywords: cardiomyopathy, noncompaction, heart failure, echocardiography, cardiac magnetic resonance imaging.

Summary

Noncompaction cardiomyopathy (NCC) is a rare condition, characterized by isolated ventricular noncompaction, presenting with prominent trabeculations, thin compact miocardial layer and deep intertrabecular recesses. This article will review current information about NCC, pathogenesis, clinical presentation, novelties in the diagnosis and management of the disease.

We report the presentation of a NCC patient, who was first diagnosed at the age of 57 . Here we present his disease history as well as his condition after 5 years from the establishment of the diagnosis.

The true prevalence of the disease is still unknown because of the absence of clear diagnostic criteria. It is a genetically heterogeneous disorder, usually diagnosed in the early childhood. Several responsible genes have been identified, although their specificity is low. Clinical presentation varies from the absence of symptoms to heart failure, systemic embolic events and arrhythmias. The principal diagnostic tool is echocardiography, but cardiac magnetic resonance imaging has been used increasingly. There are new diagnostic methods, who could facilitate diagnostics in the future clinical practice. Management is not specific and directed at the main clinical manifestations.

The most important challenge regarding NCC is the clear differentiation from the normal variants of healthy hearts and other cardiomyopathies because prognosis and management may significantly differ.

Correspondence to: gabrieleg13@gmail.com

Gauta 2022-01-05 